\title{
Quality protein maize (QPM) as balance nutrition for human diet
}

\section{Introduction}

Maize consists of three main parts- the hull or bran coat with high fiber content, germ rich in oil and starchy endosperm. The normal maize grain under Indian conditions on an average, contains $14.9 \%$ moisture, $11.1 \%$ protein, $3.6 \%$ fat, $2.7 \%$ fiber, $66.2 \%$ other carbohydrates and $1.5 \%$ minerals (National Institute of Nutrition, 2002). Maize kernel protein is made up of five different fractions. The percentage of different fractions to total nitrogen in maize kernel is albumin $7 \%$, globulin $5 \%$, non-protein nitrogen $6 \%$, prolamine $52 \%$ and glutelin $25 \%$ and the left over $5 \%$ is residual nitrogen. Protein being the primary structural and functional component of every living cell is one of the most important ingredients that determine the quality of food and feed.

In normal maize grain the quality of protein is poor due to the presence of largest concentration of an alcohol soluble protein fraction 'prolamine' also known as 'Zein' in the endosperm. The amount of this alcohol soluble protein fraction zein is low in immature maize. They increase as the grain matures. Zein is very low in lysine and tryptophan content. On the other hand, zein fractions contain very high amount of leucine and imbalanced proportion of isoleucine. On the whole, the ill proportion of all these four essential amino acids in maize due the high content of zein results into the poor quality of protein in normal maize. The high quality of protein in other fractions in other parts of maize kernel becomes recessive due to the dominance of zein in normal maize. The poor quality of protein in normal maize affects its 'Biological value' i.e. the availability of protein in the body.

The majority maize is the staple cereal food throughout the world. Therefore it was realized to improve the biological value of protein in maize genotypes. For this purpose, a new corn type known as 'Quality Protein Maize' (QPM) was developed by lowering the concentration of zein by $30 \%$. As a result, the concentration of two essential amino acids viz., lysine and tryptophan in grain was increased in QPM genotypes as compared to normal grain maize genotypes. The lower content of leucine in QPM further balances the ratio of leucine to isoleucine content (Table 1) (Table 2). The balanced proportion of all these essential amino acid in Quality Protein Maize (QPM) enhanced the biological value of protein. The True Protein Digestibility of normal maize and Quality Protein Maize is almost same, but the biological value of normal maize is just half as compared to that of QPM varieties. Rather, the biological value of QPM is highest among all the food grains (Figure 1) owing to the reason that all cereals except QPM are deficient in lysine, an essential amino acid and all pulses are deficient in methionine, the other essential amino acid.
Volume 6 Issue 2 - 2017

\author{
Mamatha $\mathrm{H},{ }^{\prime}$ Meena MK,' Pushpa Chethan \\ $\mathrm{Kumar}^{3}$ \\ 'Jawaharlal Nehru Technological University, India \\ ${ }^{2}$ Department of Crop Physiology, University of Agricultural \\ Sciences, India \\ ${ }^{3}$ Scientist, Division of Post Harvest Technology, ICAR-Indian \\ Institute of horticultural research, India
}

Correspondence: Mamatha H, Jawaharlal Nehru Technological University, India, Email mamtha.patel@gmail.com

Received: October 12, 2016 | Published: January 30, 2017

Table I Comparisons on essential amino acid content in normal maize and quality protein maize

\begin{tabular}{llll}
\hline \multirow{2}{*}{ Sl.No } & Amino acid & \multicolumn{2}{c}{ Amino acid content (mg per g N) } \\
\cline { 3 - 4 } & & Normal grain & QPM grain \\
\hline 1 & Lysine & 177 & 256 \\
2 & Isoleucine & 206 & 193 \\
3 & Leucine & 827 & 507 \\
4 & Sulphur amino acid & 188 & 188 \\
5 & Aromatic amino acid & 505 & 502 \\
6 & Theronine & 213 & 199 \\
7 & Tryptophan & 35 & 78 \\
\hline
\end{tabular}

Table 2 Protein quality of maize grain

\begin{tabular}{llll}
\hline SI. No & Quality measure parameters & $\begin{array}{l}\text { Normal } \\
\text { grain }\end{array}$ & $\begin{array}{l}\text { QPM } \\
\text { grain }\end{array}$ \\
\hline 1 & True proteins digestibility (\%) & $82-91$ & 92 \\
2 & Biological value (\%) & $40-47$ & 80 \\
3 & Amount needed for equilibrium & 547 & 230 \\
\hline
\end{tabular}

\section{Uses of quality protein maize}

\section{For food and nutritional security}

i. QPM produces $70-100 \%$ more of lysine and tryptophan than the most modern varieties of tropical maize. These two amino acids 
allow the body to manufacture complete proteins, thereby eliminating wet-malnutrition. In addition tryptophan can be converted in the body to Niacin, which theoretically reduces the incidence of Pellagra. ${ }^{1-3}$

ii. Therefore, the QPM can be utilized for diversified purposes in food and nutritional security as infant food, health food/mixes, convenience foods, specialty foods and emergency ration, in fulfilling the protein requirements of different sections of society (infants, lactating mothers' convalescing patients, Kwashiorkor diseased, old persons and infirm, etc.) to prevent malnutrition.

\section{Providing nutritious feed}

Maize is the major source of feed that indicates growing demand for maize globally. India being the 5th largest poultry producer in the world with a very high growth rate of $7.94 \%$ during $2000-01$ to $2006-$ 07 . Similarly, the poultry growth rate in India is very high and $49 \%$ of the total maize production is consumed as feed in poultry sector in India. This sector has also further enormous growth potential (about $15 \%$ p.a.) that would raise the further demand of QPM. Therefore, Quality Protein Maize (QPM) with its high carbohydrates, fats, better quality proteins, some of vitamins and minerals, it is nutritious feed for poultry, livestock, swine, fish, etc. Use of QPM as poultry feed leads to early development of broilers, save energy and feed, and also the extra cost incurred on lysine and tryptophan fortification.

\section{Promoting maize based entrepreneurship}

The nutritious products developed from QPM can replace fancied and highly priced industrial foods. These products can also be prepared in villages and thus could be a great source of rural entrepreneurship. Therefore, QPM based rural industries has a wider scope for employment generation and rural prosperity.

\section{Feed trials on QPM nutritional benefits}

The results of the feeding trials on children's for 6months at Rajendra Agricultural University, Pusa Bihar on the efficacy of Quality Protein Maize over normal maize grain revealed that the anthropometric measurements i.e. body weight (Figure 2) and arm circumference (Figure 3) of children's fed with QPM were remarkably higher compared to children fed with normal maize grain . Therefore the QPM could be a cheaper source of protein for children and can thus be used effectively as mid-day meal for which Bihar state of India has already taken good lead.

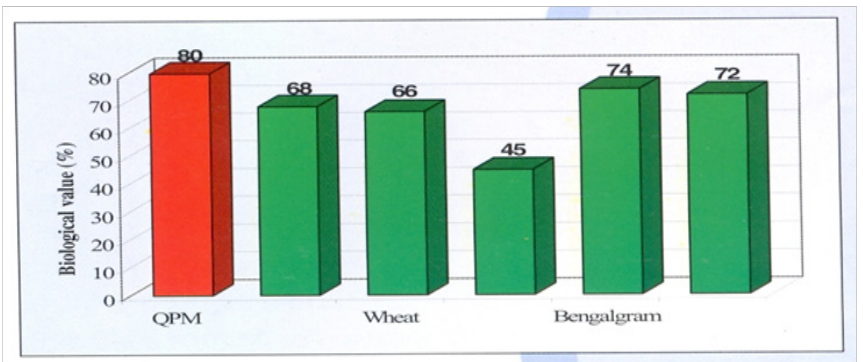

Figure I Biological value of QPM in comparison to other cereals and pulses.

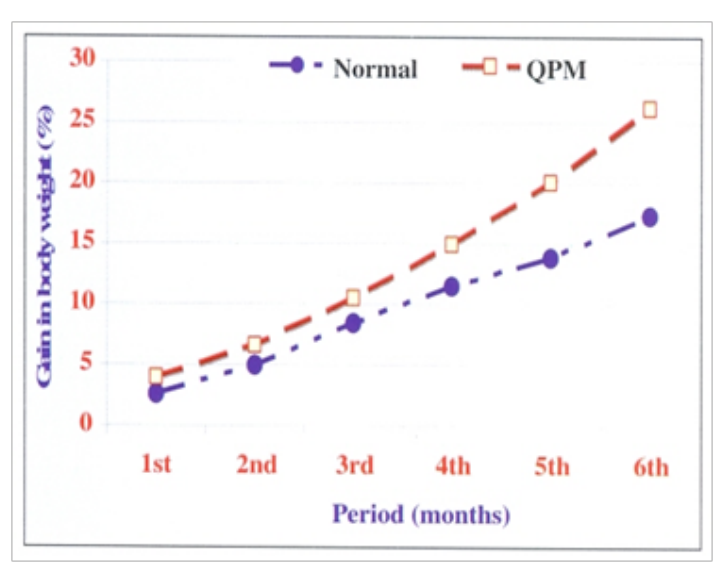

Figure 2 Comparative gains in body weight of Children fed with normal and QPM grain with normal and QPM.

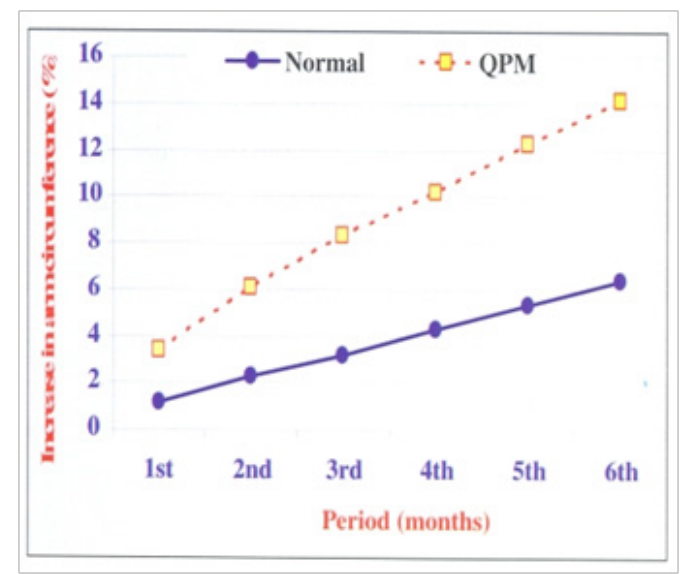

Figure 3 Comparative growth in arm circumference of children's fed.

\section{Summary}

i. QPM maintains high nutritive value compared normal maize grain.

ii. It provides balanced nutrition for human consumption (pregnant women \& children's).

iii. Biological value of QPM is more over the cereals and pulses.

iv. It will give opportunities to village peoples for employment.

v. Its cultivation is eco-friendly \& it provides better health to human being as well as cattles.

\section{Acknowledgements}

None.

\section{Conflict of interest}

The author declares no conflict of interest. 


\section{References}

1. Directorate of Maize Research, New Delhi, India.
2. www.maizeindia.org

3. National Institute of Nutrition; 2002. 